\title{
Miranda's Constitutional Difficulties: A Reply to Professor Schulhofer
}

\author{
Joseph D. Grano†
}

In a recent article, entitled "Reconsidering Miranda,"1 Professor Stephen Schulhofer attempts to defend Miranda $v$. Arizona ${ }^{2}$ against various levels of challenge. Most fundamentally, he attempts to refute the claim that Miranda represents an illegitimate exercise of judicial power. Somewhat less fundamentally, he also argues that Miranda involved not only a plausible but a correct-indeed a logically necessary ${ }^{3}$-interpretation of the Constitution. Least fundamentally, Professor Schulhofer attempts to rebut the policy claim that Miranda has reduced the effectiveness of law enforcement.

Putting aside the policy question, ${ }^{4}$ this article maintains that Professor Schulhofer has yet to answer the most telling constitutional arguments against Miranda. With regard to the legitimacy issue, Professor Schulhofer fails fully to perceive, and thus does not address, the basis of the challenge. At the level of interpretational dispute, Professor Schulhofer's arguments, though more powerful, are incomplete and, to some extent, based upon faulty premises.

Section I of this article outlines the objection that Miranda, at least as the Supreme Court now understands it, represents an exercise of judicial authority not conveyed by the Constitution. Section II argues that the legitimacy objection can be overcome, but only by a rather implausible interpretation of the word "compelled." The rock and hard place are apparent: plausibility comes at the

$\dagger$ Distinguished Professor of Law, Wayne State University.

1 Stephen J. Schulhofer, Reconsidering Miranda, 54 U.Chi.L.Rev. 435 (1987).

2384 U.S. 436 (1966).

${ }^{3}$ Schulhofer, 54 U.Chi.L.Rev. at 453 (cited in note 1) (claiming that a finding of compulsion in custodial interrogation follows a fortiori from the Court's holding in Griffin v. California, 380 U.S. 609,615 (1965), that compulsion exists when a prosecutor comments on the accused's failure to testify).

1 I previously have criticized the policy assumptions underlying modern confessions law. Joseph D. Grano, Police Interrogation and Confessions: A Rebuttal to Misconceived Objections, Occasional Paper, The Center for Research in Crime and Justice, New York University School of Law (1987). 
cost of legitimacy; legitimacy comes at the cost of plausibility.

\section{The Legitimacy ObJection}

Professor Schulhofer succeeds in avoiding the force of the legitimacy objection by ignoring both its nature and its primacy. $\mathrm{He}$ begins his article by positing Miranda's three holdings: first, that informal pressure to speak can constitute "compulsion" within the meaning of the fifth amendment; second, that informal compulsion is present in any custodial interrogation of a suspect; and third, that specified warnings are required to dispel the compelling pressure. ${ }^{5}$ With regard to the first, Professor Schulhofer immediately and correctly observes that not even the slightest doubt about legitimacy can arise, for "it is a normal act of interpretation for a court to consider whether 'compulsion' was intended to cover informal pressures." Although the Court's authority to interpret the constitution cannot assure infallibility, "wrong" decisions, we all may agree, may be perfectly legitimate."

Still avoiding the legitimacy issue, Professor Schulhofer next attempts to defend the view that custodial interrogation is inherently compelling within the meaning of the fifth amendment. Notwithstanding this conclusion, and somewhat inconsistent with it, Professor Schulhofer then discusses the Court's "conclusive presumption" of compulsion from the mere existence of custodial interrogation. ${ }^{8}$ Only here does Professor Schulhofer find it necessary to address legitimacy. Conceding that one can imagine a case in which a single custodial question would not actually be compelling, he states:

S Schulhofer, 54 U.Chi.L.Rev. at 436 (cited in note 1). He adds that the requirement of specified warnings "raises the concerns about judicial legislation that usually preoccupy $M i$ randa's critics." Id. In what follows, however, Professor Schulhofer recognizes that the more fundamental legitimacy objection is grounded in Miranda's use of a conclusive presumption with regard to compulsion, not in its specification of warnings. Indeed, he devotes only two pages to a defense of the warnings.

- Schulhofer, 54 U.Chi.L.Rev. at 436 (cited in note 1).

7 The legitimacy of judicial review depends upon the premise that Marbury v. Madison, 5 U.S. 137 (1803), was correctly decided. Neither this premise, however, nor the further premise that the Court's interpretations of the constitution are final, Cooper v. Aaron, 358 U.S. 1, 18 (1958), assures infallibility. See, e.g., Brown v. Allen, 344 U.S. 443, 540 (1953) (Jackson concurring). The risk of mistake is inherent in the Marbury-Cooper judicial function; the risk of unwarranted assumption of power is not.

- If custodial interrogation actually is inherently compelling in all cases, a conclusive presumption of compulsion should not be necessary. Without arguing in the alternative, Professor Schulhofer seems to defend both the proposition that custodial interrogation always is compelling and the proposition that a conclusive presumption of compulsion is justified even though actual compulsion sometimes is lacking. 
Because such a case is conceivable, and because the Court's per se rule would find a fifth amendment violation even in that case, some critics conclude that Miranda's second holding is itself prophylactic, that the Court did not simply interpret the meaning of compulsion but rather replaced the nocompulsion rule with a much broader prohibition. ${ }^{9}$

Several points warrant emphasis at the outset. First, the Supreme Court, not "some critics," has concluded that the Miranda requirements are only prophylactic safeguards to assure that compulsion does not occur. ${ }^{10}$ Second, Professor Schulhofer in any event does not really challenge the claim, for he assumes the burden of defending "conclusive presumptions and related forms of prophylactic rules" as vital "aids to adjudication."11 Third, to the extent the quotation gives any indication of the basis of the objection to prophylactic rules, it does so only in its rather cryptic last clause.

Having failed to articulate the basis of the legitimacy objection, Professor Schulhofer defends prophylactic rules simply by maintaining that irrebuttable presumptions often are more efficacious than rebuttable presumptions:

But in appropriate circumstances, the same logic applies to both kinds of presumptions. When an assessment is complex and often beyond the ken of judges . . . or when proof of the circumstances crucial to a fact-bound judgment is largely within the control of one party, . . . a conclusive presumption may be the best way, over the run of cases, to minimize adjudicatory error. ${ }^{12}$

For Professor Schulhofer, then, the "proper question" is simply whether a conclusive presumption of compulsion "is an appropriate adjudicatory tool" in the context of custodial interrogation. ${ }^{13}$

Unfortunately, this analysis completely overlooks the "proper question." A prophylactic rule in the constitutional context is a

- Schulhofer, 54 U.Chi.L.Rev. at 448 (cited in note 1) (emphasis in original), citing as illustrative of the critics Joseph D. Grano, Prophylactic Rules in Criminal Procedure: A Question of Article III Legitimacy, 80 Nw.U.L.Rev. 100 (1985). That Professor Schulhofer concedes the existence of cases without compulsion contradicts his claim that any custodial interrogation is inherently compelling. See note 8.

${ }^{10}$ See, e.g., New York v. Quarles, 467 U.S. 649, 657 (1984); Michigan v. Tucker, 417 U.S. $433,444-45$ (1974). See also note 15.

11 Schulhofer, 54 U.Chi.L.Rev. at 448 (cited in note 1).

12 Id. at 450 .

13 Id. at 451 . 
court-created rule that can be violated without violating the Constitution itself. ${ }^{14}$ As the Supreme Court has explained with regard to Miranda, the police may violate Miranda's prophylactic rules without necessarily violating the fifth amendment. ${ }^{15}$ The proper question, therefore, is whether the Constitution grants the Supreme Court authority to reverse a conviction, particularly a state conviction, ${ }^{16}$ when no constitutional violation has occurred.

Consider the issue in the following context. While the prosecution may not use for any purpose the defendant's involuntary or actually compelled statements, ${ }^{17}$ the Supreme Court has held that the prosecution may impeach a testifying defendant with a statement taken in violation of Miranda, provided the statement is voluntary. ${ }^{18}$ Imagine, then, a state case in which the state's highest court has upheld the prosecution's use of a defendant's statement both in presenting its case-in-chief and in impeaching the defendant's credibility. On review, the Supreme Court concludes that although the statement was taken in violation of Miranda, it was not compelled and hence was properly used for impeachment purposes. ${ }^{19}$ Nevertheless, adhering to current doctrine, the Supreme

14 Michigan v. Payne, 412 U.S. 47, 53 (1973) ("It is an inherent attribute of prophylactic constitutional rules, such as [the rule] established in Miranda . . ., that their retrospective application will occasion windfall benefits for some defendants who have suffered no constitutional deprivation."). See also Grano, 80 Nw.U.L.Rev. at 105 (cited in note 9).

${ }^{15}$ Oregon v. Elstad, 470 U.S. 298, 305-307 and n.1, 309 (1985); New York v. Quarles, 467 U.S. at 654, 655 n.5, 657-58 and n.7. See also New Jersey v. Portash, 440 U.S. 450, 459 (1979).

While arguing that Miranda as originally written was not prophylactic, Professor Yale Kamisar, one of Miranda's most ardent defenders, conceded in a debate with me that "there is no shortage of language in recent Supreme Court opinions indicating that the police may violate Miranda without violating the Constitution." Eighth Sidney W. Hatcher Memorial Lecture, Walter F. George School of Law, Mercer University, February 12, 1987; Letter from Yale Kamisar on file with The University of Chicago Law Review. I have argued that Miranda itself contains the seeds of a prophylactic interpretation. Grano, 80 Nw.U.L.Rev. at 107-09 (cited in note 9).

${ }^{16}$ The Supreme Court's imposition of prophylactic rules on the federal courts through its "supervisory power" also raises difficult questions. See Sara Sun Beale, Reconsidering Supervisory Power in Criminal Cases: Constitutional and Statutory Limits on the Authority of the Federal Courts, 84 Colum.L.Rev. 1433 (1984).

17 New Jersey v. Portash, 440 U.S. at 459.

18 Oregon v. Hass, 420 U.S. 714, 722 (1975). This holding by itself proves Miranda's prophylactic status. See also Harris v. New York, 401 U.S. 222, 226 (1971).

10 Professor Schulhofer believes that prophylactic rules are particularly appropriate when "an assessment is complex and often beyond the ken of judges." Schulhofer, 54 U.Chi.L.Rev. at 450 (cited in note 1). Professor Schulhofer also believes that "in any ranking of the issues that properly demand some form of prophylactic rule, the problem of determining compulsion in the context of custodial interrogation wins the prize hands down." Id. at 453. The impeachment doctrine, which requires courts to determine voluntariness, refutes the suggestion that voluntariness determinations are "beyond the ken" of judges. 
Court reverses the state conviction because the prosecution used the same non-compelled statement not just for impeachment purposes but also in proving its case. ${ }^{20}$

The issue raised by the hypothetical is whether the judicial power conveyed by Article III of the Constitution ${ }^{21}$ authorizes the Supreme Court to reverse a state conviction when the Constitution has not been violated. The authority to require reversal in the hypothetical goes beyond the Court's long recognized authority to review the judgments of state courts on questions of federal law. ${ }^{22}$ To require reversal, the Supreme Court must either have authority to create a body of federal common law that is binding on the states ${ }^{23}$ or, despite separate sovereignties, have some kind of supervisory power over state courts. ${ }^{24}$ In a previous article, I developed at length an argument that Article III does not give the Court such authority. ${ }^{25}$ I maintained that such authority could not be justified as "constitutional common law," authority, or as a kind of federal question jurisprudence. Professor Schulhofer, however, does not attempt to justify prophylactic rules under any of these theories, or indeed under any other constitutional theory. Rather, he ignores altogether the question of the source of the Court's authority to reverse state convictions when the Constitution has not been violated.

To the extent that Professor Schulhofer seeks to justify such power at all, he does so by a two step argument. First, he posits that conclusive presumptions "are a pervasive feature of judicial decision making."27 Second, conceding that pervasiveness cannot prove legitimacy, he simply insists "that the Court would face enormous adjudicatory burdens if resort to conclusive presumptions was never permissible."28 To illustrate these "enormous burdens," he depicts the futility of the judiciary trying to ascertain on

${ }^{20}$ See Oregon v. Elstad, 470 U.S. at 306-07, 317-18 (reiterating per se rule of exclusion with regard to the state's case-in-chief when Miranda is violated).

${ }^{21}$ See U.S.Const. art. III, \& 2 (defining the scope of the judicial power).

${ }^{22}$ Cohens v. Virginia, 19 U.S. 264 (1821); Martin v. Hunter's Lessee, 14 U.S. 304 (1816).

${ }^{23}$ But see Erie R.Co. v. Tompkins, 304 U.S. 64, 78 (1938) (mere grant of jurisdiction does not authorize federal courts to promulgate a general federal common law).

24 But see Smith v. Phillips, 455 U.S. 209, 221 (1982) ("Federal courts have no supervisory authority over state judicial proceedings and may intervene only to correct wrongs of constitutional dimension.").

${ }^{25}$ Grano, 80 Nw.U.L.Rev. 100 (cited in note 9).

${ }^{26}$ See Henry P. Monaghan, The Supreme Court, 1974 Term-Foreword: Constitutional Common Law, 89 Harv.L.Rev. I (1975) (suggesting the legitimacy of a "constitutional common law").

${ }^{27}$ Schulhofer, 54 U.Chi.L.Rev. at 448 (cited in note 1).

28 Id. at 450. 
a case-by-case basis whether "a few punches or kicks" would render a confession involuntary. Thus, he claims the Court eventually recognized "that even the voluntariness test had to include prophylactic rules: a single blow would render a confession involuntary per se."29

Besides failing to address the Article III issue, this argument reflects a basic misunderstanding both of the nature of conclusive presumptions and of the Court's use of per se rules. Conclusive presumptions differ in kind, not simply degree, from rebuttable presumptions. Indeed, conclusive presumptions are not evidentiary or adjudicatory devices at all, but rather substantive rules of law:

In the case of what is commonly called a conclusive or irrebuttable presumption, when fact $B$ is proven, fact $A$ must be taken as true, and the adversary is not allowed to dispute this at all. For example, if it is proven that a child is under seven years of age, the courts have stated that it is conclusively presumed that he could not have committed a felony. In so doing, the courts are not stating a presumption at all, but simply expressing the rule of law that someone under seven years old cannot legally be convicted of a felony. ${ }^{30}$

The conclusive presumption operates, therefore, to make the presumed fact "legally immaterial."

Care must be taken not to confuse per se rules as such with conclusive presumptions. For example, a rule stating that unnecessarily suggestive identification procedures violate due process is a per se rule that is not dependent upon a conclusive presumption. A rule stating that unnecessarily suggestive identification procedures violate due process only if they create a substantial risk of mistaken identification, but stating also that such risk of mistake will be presumed whenever an unnecessarily suggestive procedure is used, operates as a per se rule only because of its conclusive presumption. ${ }^{32}$ While the outcome under both rules will be the same, the latter rule posits one legal test but, in reality, adopts another.

The difference also can be illustrated by considering Professor Schulhofer's voluntariness example. If the due process voluntariness test embodies the proposition that a statement is involuntary only if the suspect's will is overborne, the per se rule against even

29 Id. at $450-51$.

${ }^{30}$ Edward W. Cleary, McCormick on Evidence 966 (3d ed. 1984) (emphasis added).

31 Charles T. McCormick, Handbook of the Law of Evidence 640 n.2 (1954).

${ }^{32}$ See Grano, 80 Nw.U.L.Rev. at 114-15 (cited in note 9). 
slight physical force functions as a conclusive presumption. With fact $X$ (the use of physical force) established, the state is not permitted to refute fact $Y$ (involuntariness defined as an overborne will). Under such an analysis, of course, fact $Y$ (the existence of an overborne will) is not really part of the legal test; that is, the real legal test is something other than the posited legal test. If, on the other hand, the due process voluntariness test really embodies a normative judgment that a statement is involuntary when the police interrogation techniques are unacceptable, ${ }^{33}$ then a per se rule against physical force may simply reflect a legal conclusion about the meaning of voluntariness. Under such an analysis, a statement actually is involuntary (defined as obtained by unacceptable means) when physical force is used. ${ }^{34}$

Returning to Miranda, the Constitution itself posits the legal test: not self-incrimination but only "compelled" self-incrimination is prohibited. ${ }^{35}$ Thus the Supreme Court is not free to create but only can interpret the governing standard. If the Supreme Court concluded that custodial interrogation without warnings actually and always amounts to compulsion, we would have a per se rule, but one based on an interpretation of the word "compelled" in the fifth amendment. Under such an interpretation, the police actually would violate the fifth amendment whenever they engaged in the proscribed interrogation. What the Court has said in its recent cases, however, is not that custodial interrogation always equals actual compulsion but rather that compulsion conclusively will be presumed from custodial interrogation. ${ }^{36}$ The effect, of course, is that the Court has made the constitutional requirement of compulsion "legally immaterial."

Given that the outcome of both approaches is the same, the temptation is to insist that the legitimacy question cannot turn on such a "subtle distinction." Und Under the proffered analysis, if the

${ }^{33}$ Despite the Court's overborne will rhetoric, this more accurately describes the due process voluntariness doctrine. See Joseph D. Grano, Voluntariness, Free Will and the Law of Confessions, 65 Va.L.Rev. 859, 881, 922-3 (1979). See also the text at notes 43-47.

34 Professor Schulhofer's failure to distinguish per se constitutional rules from conclusive presumptions also is evident in his description of what he labels "reverse prophylactic rules." Schulhofer, 54 U.Chi.L.Rev. at 449 (cited in note 1). But see id. at 449-50 n.33 (implying that a difference exists between per se constitutional rules and conclusive presumptions).

${ }^{35}$ U.S.Const. amend. V. See also United States v. Washington, 431 U.S. 181, 187 (1977).

${ }^{38}$ See, e.g, Oregon v. Elstad, 470 U.S. at 306 n.1.

${ }^{37}$ See, e.g., Schulhofer, 54 U.Chi.L.Rev. at 449 n.31 (cited in note 1), describing as a "subtle distinction" my argument that Gideon v. Wainwright, 372 U.S. 335 (1963), granting indigents a sixth amendment right to appointed counsel in felony trials, employed a per se 
Court states, albeit "incorrectly," that custodial interrogation as such always equals compulsion, the legitimacy objection is overcome. But if the Court states, as it has, that compulsion must be conclusively presumed from custodial interrogation, the legitimacy objection remains viable. Even if subtle, however, the distinction is vitally important. First, while Congress may not overturn by statute interpretive decisions, it is quite conceivable that it can reject the use of conclusive presumptions. ${ }^{38}$ Second, the significance of the distinction lies precisely in the fact that the first statement entails the conclusion that the Constitution actually has been violated while the second statement makes the existence of an actual constitutional violation irrelevant. As illustrated by the impeachment example previously discussed, the second statement permits the Supreme Court to reverse a state conviction even when it must concede that actual compulsion, and hence a constitutional violation, does not exist.

Still, it might be suggested that the above analysis reduces the legitimacy objection to a semantic quibble. After all, with a slight change in emphasis, the Court always can transform a conclusive presumption into an actual constitutional interpretation and thus eliminate the legitimacy obstacle. Though not without force, this effort to trivialize the issue also should be rejected. In many instances, the Court resorts to a conclusive presumption because a holding of actual constitutional infirmity would be implausible. In the Miranda context, for example, the Court can avoid employment of a conclusive presumption only by insisting that compulsion always is present during custodial interrogation. Thus, for example, the Court would have to find actual compulsion even if a law professor, aware of his or her rights and wanting to tell the truth, responded to a single custodial question. ${ }^{39} \mathrm{~A}$ holding that the Court will not inquire into actual compulsion avoids the need for such strained judgments.

In summary, if the legitimacy objection is valid, Miranda can be defended only by an interpretation of the word "compelled" that makes every violation of Miranda an actual violation of the fifth amendment. Although this seems implausible on its face, Professor Schulhofer also tries to defend this proposition.

constitutional rule rather than a prophylactic rule. See Grano, 80 Nw.U.L.Rev. at 116-19 (cited in note 9).

${ }^{38}$ See Monaghan, 89 Harv.L.Rev. at 26-30, 36-37 (cited in note 26).

39 The example is Professor Schulhofer's. Schulhofer, 54 U.Chi.L.Rev, at 448 (cited in note 1). 


\section{The InTERPRETational Difficulty}

In a previous essay, I tried to demonstrate both that the fifth amendment concept of compulsion in the context of police interrogation must be understood as a synonym for coercion and that the concept of coercion implicates the same normative judgments as the due process voluntariness test. ${ }^{40}$ Professor Schulhofer acknowledges that "[i]f a compelled statement means an involuntary one," then Miranda's holding that custodial interrogation is inherently compelling is "fragile indeed." $"$ Viewing this as the "decisive question," he attempts to demonstrate that such a view of compulsion "would make nonsense of the privilege against self-incrimination." 42

Professor Schulhofer's argument is built upon the erroneous premise that the voluntariness test prohibits only "the use of 'deliberate means to break the suspect's will." "43 Thus, to prove his point that the concepts of compulsion and voluntariness are different, he cites several cases finding fifth amendment compulsion in which it would be implausible even to suggest that the individual's will had been overborne. ${ }^{44}$ To be sure, the black letter of the voluntariness cases almost invariably refers to overborne wills. ${ }^{45}$ Nevertheless, as Professor Kamisar illustrated years ago, the overborne will language always has obscured the Court's real reasons for excluding particular confessions. ${ }^{46}$ Indeed, if the Court meant the overborne will language to be taken literally-to be used as a test to govern analysis rather than as a shorthand statement of a conclusion-few if any of its due process opinions could have found the defendant's confession involuntary. ${ }^{47}$

While recognizing that the compulsion standard might be rec-

40 Joseph D. Grano, Selling the Idea To Tell the Truth: The Professional Interrogator and Modern Confessions Law, 84 Mich.L.Rev. 662, 683-89 (1986). See also Joseph D. Grano, Miranda v. Arizona and the Legal Mind: Formalism's Triumph Over Substance and Reason, 24 Amer.Crim.L.Rev. 243, 253-67 (1986); Grano, 65 Va.L.Rev. at 926-37 (cited in note 33).

41 Schulhofer, 54 U.Chi.L.Rev. at 442 (cited in note 1)(emphasis in original).

42 Id. For the view that the term "privilege against self-incrimination" is incorrect and misleading, see Grano, 84 Mich.L.Rev. at 683 (cited in note 40 ).

4s Schulhofer, 54 U.Chi.L.Rev. at 442 (cited in note 1).

1" Id. at 442-44.

45 See, e.g., Mincey v. Arizona, 437 U.S. 385, 401-02 (1978); Culombe v. Connecticut, 367 U.S. 568, 602 (1961) (Frankfurter and Stewart); Hopt v. Utah, 110 U.S. 574, 585 (1884).

16 Yale Kamisar, What Is An "Involuntary" Confession? Some Comments on Inbau and Reid's Criminal Interrogation and Confessions, 17 Rutgers L.Rev. 728, 755-59 (1963).

67 Even a person being tortured makes a conscious choice between yielding to the pressure and resisting further. Grano, 65 Va.L.Rev. at 880-86 (cited in note 33). 
onciled with the due process voluntariness standard by rejecting a literal reading of the overborne will language, Professor Schulhofer curiously states that "Miranda's critics cannot take this route . . . because mild interrogation pressures could then render a confession 'involuntary." "48 This claim, of course, is a non-sequitur. $M i$ randa's critics do take this route because the task, whether viewed in terms of fifth amendment compulsion or due process voluntariness, is "to sift out undue pressure, not to assure spontaneous confessions." $" 40$

Conceding at one point that "compulsion cannot be satisfied by any inconvenience resulting from failure to testify," Professor Schulhofer nevertheless draws from precedent the rather remarkable principle that compulsion exists if governmental officials apply any psychological pressure for the purpose of overcoming the suspect's unwillingness to talk. ${ }^{51}$ This pressure, in his view, is what makes custodial interrogation inherently compelling. The cases, however, do not support such a principle.

Placing considerable reliance on the principle that a public employee may not be threatened with discharge for refusing to testify, Professor Schulhofer states correctly that a statute subjecting a defendant to only a small fine for not testifying would clearly violate the fifth amendment. ${ }^{52}$ The reason, however, is not as Professor Schulhofer suggests that the fifth amendment prohibits even mild pressures but rather that the fifth amendment precludes the state from asserting a claim of right to the defendant's testimony. ${ }^{53}$ By analogy, although an officer's claim of authority to search automatically renders consent invalid, ${ }^{54}$ consent will not be deemed involuntary simply because it is given under circumstances of mild

4s Schulhofer, 54 U.Chi.L.Rev. at 443 (cited in note 1).

49 Miranda v. Arizona, 384 U.S. 436, 515 (1966) (Harlan, Stewart, and White dissenting) (emphasis in original).

so Schulhofer, 54 U.Chi.L.Rev. at 444 (cited in note 1).

s1 Id. at $445-46$.

52 Id. at 443.

53 Such a statute would implicate the fifth amendment "in its most pristine form." Portash, 440 U.S. at 459. Indeed, as Professor Schulhofer seems to recognize, Miranda had to justify extending the fifth amendment's reach from its historical concern with legal process and formal sanctions to the somewhat different concern of informal pressure. (This extension of the fifth amendment itself can be criticized. Grano, 65 Va.L.Rev. at 926-27 (cited in note 33)). Extending the fifth amendment to cover informal pressure, however, does not necessarily require that pressure analysis now be factored into all of the amendment's historical applications. Rather, Professor Mayers is correct in observing that the fifth amendment has come to embody several distinct rules, each with a somewhat different line of development. Lewis Mayers, Shall We Amend the Fifth Amendment? 1 (1959).

64 Bumper v. North Carolina, 391 U.S. 543, 548-50 (1968). 
pressure. ${ }^{55}$ The issues of claim of authority and undue pressure $a b-$ sent such a claim are analytically distinct, and for historical reasons they have been treated differently in the fifth amendment context.

Professor Schulhofer is on firmer ground when he relies on Griffin v. California, ${ }^{56}$ which prohibited comment on the defendant's failure to testify at trial. "If a comment on silence generates impermissible pressure to speak at trial (where the comment adds only marginally to inferences the jury will draw anyway), can we say that a police officer's request for information, addressed to an unwarned suspect in custody, does not create impermissible pressure?"'s7 Of course, Griffin may be viewed as an impermissible penalty rather than a compulsion case, because the defendant did not yield to the pressure. Professor Schulhofer probably is correct, however, in viewing such an interpretation of Griffin as lame, for the issue of what constitutes an impermissible penalty must have something to do with the issue of what constitutes compulsion. More plausibly, Griffin may be viewed as a case dealing with a core fifth amendment concern: the defendant's trial right not to be put under oath to testify. ${ }^{88}$ Finally, as Professor Schulhofer recognizes, Griffin, which was decided just one year before Miranda, itself can be challenged.

As Professor Schulhofer recognizes, "debate about the meaning of compulsion cannot be settled simply by resort to stare decisis." $" 59$ Thus, to the extent that Griffin turns on a conclusion that even exceedingly mild pressure constitutes compulsion, rather than on one of the bases suggested above, it requires defense. Observing accurately that the Court has shown no inclination to reconsider Griffin, Professor Schulhofer defends Griffin by suggesting that the Court could overrule its holding only by rejecting both the holdings in the employment discharge cases and the unchallenged understanding that the fifth amendment would not permit the state

Bs United States v. Watson, 423 U.S. 411,424 (1976); Schneckloth v. Bustamonte, 412 U.S. 218,224 (1973).

380 U.S. 609 (1965).

s7 Schulhofer, 54 U.Chi.L.Rev. at 453 (cited in note 1).

${ }^{58}$ See note 53. There is no doubt that the Court scrutinizes more strictly claims of compulsion relating to trial testimony. Compare Brooks v. Tennessee, 406 U.S. 605, 612 (1972) (invalidating statute that required defendant to testify prior to other defense witnesses) with Williams v. Florida, 399 U.S. 78, 83 (1970) (upholding a statute requiring the defendant to provide pretrial discovery to the prosecutor). Griffin also may reflect the concern that a jury may give undue weight to the defendant's failure to testify.

${ }^{59}$ Schulhofer, 54 U.Chi.L.Rev. at 442 (cited in note 1). 
to fine a person for refusing to testify.$^{60}$ As already indicated, however, the outcomes in these latter areas are not dependent upon a conclusion that even mild pressure constitutes compulsion. ${ }^{61}$ Griffin, in short, cannot be defended by positing a parade of horribles that might follow its demise.

While the meaning of compulsion in an argument about first principles ultimately cannot be decided by the weight of precedent, it is worthwhile to observe that the conflict in the cases is not, as Professor Schulhofer implies, simply between Griffin and Miranda, on the one hand, and a few post-Miranda cases on the other. Outside the context of formal sanctions, the Supreme Court always has treated "compelled" and "involuntary" as virtually synonymous. When, long before Miranda, the Court first suggested that the fifth amendment applied to police interrogation in federal proceedings, the Court employed a voluntariness test. ${ }^{62}$ Likewise, in federal cases involving the admissibility of a defendant's statements obtained at the preliminary examination-cases indubitably governed by the fifth amendment-the Court applied the voluntariness standard of the confession cases. ${ }^{63}$ Similarly, the Court applied a voluntariness test in cases presumably subject to the fifth amendment $^{64}$ but not governed by Miranda because of the nonretroactivity of that decision. ${ }^{65}$ The Court also applied the same voluntariness test to cases of non-custodial interrogation ${ }^{66}$ and in other fifth amendment contexts. ${ }^{.7}$

In short, with the exception of Miranda and possibly Griffin, the Court's fifth amendment cases involving informal pressure al-

${ }^{\circ}$ Id. at 443.

61 See notes 52-55 and accompanying text.

${ }^{62}$ Bram v. United States, 168 U.S. 532, 542, 558, 562 (1897). Subsequent Supreme Court decisions in federal cases employed the same voluntariness standard. See, e.g., Wan v. United States, 266 U.S. 1, 14 (1924). Even in reviewing state cases, the Court saw no difference between the federal fifth amendment standard and the due process voluntariness standard. See, e.g., Ashcraft v. Tennessee, 322 U.S. 143, 154 n.9 (1944).

os Powers v. United States, 223 U.S. 303, 313-14 (1912); Wilson v. United States, 162 U.S. 613, 623 (1896). See also Stephen J. Markman, The Fifth Amendment and Custodial Questioning: A Response to "Reconsidering Miranda," 54 U.Chi.L.Rev. 938, 941-42 (1987).

o4 Malloy v. Hogan, 378 U.S. 1, 8 (1964) (applying the fifth amendment self-incrimination clause to the states). At the least, Malloy applied to those cases in which the state activity and trial occurred after the date of its decision.

os See, e.g., Frazier v. Cupp, 394 U.S. 731, 738-39 (1969).

of See, e.g., Beckwith v. United States, 425 U.S. 341, 348 (1976). Professor Schulhofer does not suggest that Miranda applies in the non-custodial context.

${ }^{67}$ See, e.g., United States v. Washington, 431 U.S. 181, 186-88 (1977) (grand jury). The Court even has relied on the voluntariness doctrine in employee discharge cases. See, e.g., Garrity v. New Jersey, 385 U.S. 493, 496-500 (1967). 
ways have treated a compelled statement as an involuntary one. Moreover, no case, including Miranda, ever has suggested that either the pressure of mere questioning or the pressure of custody without questioning is sufficient by itself to render a statement compelled or involuntary. Yet Professor Schulhofer insists that fifth amendment precedent requires that we treat as compelled-now distinguished from involuntary-a statement obtained by directing a single question to a suspect only moments after he has been taken into custody. No more than language or logic, the cases cannot support this burden.

If, as Professor Schulhofer claims, compulsion results from any psychological pressure designed to overcome a suspect's unwillingness to talk, non-custodial interrogation also must be "inherently compelling." ${ }^{68}$ By not criticizing Miranda's limitation to custodial interrogation, Professor Schulhofer implicitly concedes that the concept of compulsion, like that of voluntariness, must be concerned with degrees of pressure, with sifting out undue pressure. Nevertheless, he insists that every successful custodial interrogation, without some kind of Miranda protection, yields a "compelled" statement and violates the fifth amendment. Given that this implausible view, taken seriously, ultimately would require the abolition of police interrogation, in that Miranda's procedural litany cannot eliminate the mild pressure of which he complains, ${ }^{69}$ Professor Schulhofer perhaps should explain what makes such a view so appealing to him. ${ }^{70}$

${ }^{68}$ As a factual matter, many non-custodial interrogations exceed in pressure many custodial ones. On the aggregate, however, custodial interrogation undoubtedly exerts more pressure. Some may want to use this conclusion to defend an irrebuttable presumption of compulsion in the custodial context, but this would bring us back to the legitimacy objection.

69 Given his view of compulsion, Professor Schulhofer understandably is forced to conclude that Miranda did not go far enough. Schulhofer, 54 U.Chi.L.Rev. at 454, 461 (cited in note 1).

70 To the extent that the constitutional definition of compulsion requires normative judgments, it may seem that one's views on this issue are not susceptible to logical debate but ultimately must depend upon intuitive judgments. See George M. Dix, Mistake, Ignorance, Expectation of Benefit, and the Modern Law of Confessions, 1975 Wash.U.L.Q. 275, 330 . Unconvinced by such a relativistic perspective, I have attempted in other essays to elaborate reasons to prefer a definition of compulsion that permits the interrogator to exert some pressure on the suspect and to employ tactics designed to outwit him. Grano, Occasional Paper (cited in note 4); Grano, 84 Mich.L.Rev. at 676-89 (cited in note 40). In my view, Professor Schulhofer has not provided policy support for his unconventional proposals regarding the meaning of compulsion. To the extent that strained interpretations of the Constitution ever can be justified, they would seem to require the most compelling of policy arguments. 


\section{CoNCLUSION}

Under the Court's current view, Miranda imposed on the states mere prophylactic rules that can be violated without necessarily violating the Constitution. By not explaining the source of the Court's authority to impose such rules, Professor Schulhofer leaves the decision subject to a challenge of illegitimacy. Under the view of Miranda that Professor Schulhofer would prefer, every $M i$ randa violation would amount to fifth amendment compulsion. Professor Schulhofer has shown neither that such a view is plausible nor that it is desirable.

\section{Postscript}

Defending Professor Schulhofer's thesis, Professor David Strauss, in The Ubiquity of Prophylactic Rules, ${ }^{71}$ argues, first, that the assertion that rebuttable and conclusive presumptions differ in kind not degree "rings false" and "proves false,"72 and, second, that prophylactic rules are pervasive in constitutional law.

Faretta $v$. California ${ }^{73}$ can be used to illustrate the difference between rebuttable and conclusive presumptions. In Faretta, the Supreme Court held that the sixth amendment confers both the right to have the assistance of counsel and the opposite right to proceed pro se. ${ }^{74}$ Nevertheless, in effect creating a rebuttable presumption against waiver of counsel, the Court emphasized that demanding waiver criteria must be satisfied before the right of selfrepresentation is triggered..$^{76}$ Had the Faretta Court gone further, however, and adopted a conclusive presumption that an unrepresented defendant has not made a valid waiver, its presumption would have been the equivalent of a rule of law that waiver of counsel, and thus self-representation, is neither protected constitutionally nor permitted. Unlike a rebuttable presumption against waiver, a conclusive presumption against waiver could not have coexisted with a right of self-representation. Conclusive presumptions are substantive rules of law, not adjudicatory devices. ${ }^{76}$

${ }^{71}$ David A. Strauss, The Ubiquity of Prophylactic Rules, 55 U.Chi.L.Rev. 190 (1988).

72 Id. at 192.

73422 U.S. 806 (1975).

${ }^{74}$ Contra, Joseph D. Grano, The Right to Counsel: Collateral Issues Affecting Due Process, 54 Minn.L.Rev. 1175, 1179-1208 (1970). Because it interpreted actual sixth amendment requirements, Faretta raises no legitimacy question.

75 422 U.S. at 835-36.

7e Professor Strauss suggests that my real objection to Miranda either is or ought to be that the Court did not consider adequately whether a conclusive presumption is required to minimize the sum of administrative and error costs. Strauss, 55 U.Chi.L.Rev. at 194 (cited 
Professor Strauss insists, however, that a court always can fashion a rebuttable presumption that is virtually impossible to overcome, and accordingly that "there is no sensible reason to distinguish between such a barely rebuttable presumption and the explicitly conclusive presumption of Miranda."77 Such an argument is premised upon judicial bad faith. Moreover, bogus rebuttable presumptions should be seen for what they really are. ${ }^{78}$

The important issue, as Professor Strauss recognizes, is whether prophylactic rules that function as conclusive presumptions are illegitimate in constitutional law. ${ }^{79}$ Professor Strauss's defense of prophylactic rules relies primarily on the proposition that such rules are pervasive. ${ }^{80}$ Professor Stauss's claim may be disputed. To take but one example, Professor Strauss maintains that Lovell $v$. Griffin ${ }^{81}$ promulgated a "judge-made prophylactic rule designed to implement the purposes of the first amendment." 82 The Court in Lovell invalidated an ordinance that gave a city manager unfettered discretion to grant permission for the distribution of literature. The Court said this:

We think that the ordinance is invalid on its face. Whatever the motive which induced its adoption, its character is such that it strikes at the very foundation of the freedom of the press by subjecting it to license and censorship. The struggle for the freedom of the press was primarily directed against the power of the licensor. ... . [T] he prevention of that restraint was a leading purpose in the adoption of the constitutional provision. ${ }^{83}$

in note 71). As the text reveals, this is not my objection.

77. Id. at 192.

${ }^{78}$ Grano, 80 Nw.U.L.Rev. at 147 n.303 (cited in note 9).

79 Professor Strauss ponders my view of conclusive presumptions that work against defendants. Strauss, 55 U.Chi.L.Rev. at 191 n.10 (cited in note 71). In New York v. Belton, 453 U.S. 454, 460 (1981), for example, the Court held that under the search incident to arrest rule, the passenger compartment of a car is generally, if not inevitably, within an arrested occupant's reach. If the Court employed error and administrative costs to determine actual fourth amendment reasonableness, Belton is legitimate, though perhaps incorrect. See Joseph D. Grano, Rethinking the Fourth Amendment Warrant Requirement, 19 Amer.Crim.L.Rev. 603, 646-47 (1982) (Belton incorrect). If the Court said, instead, that the Constitution is violated if the search exceeds actual reach, but that courts must conclusively presume that the passenger compartment is within a recent occupant's reach, it acted illegitimately.

so Strauss, 55 U.Chi.L.Rev. at 190, 195 (cited in note 71).

s1 303 U.S. 444 (1938).

${ }^{82}$ Strauss, 55 U.Chi.L.Rev. at 197 (cited in note 71).

8s 303 U.S. at $451-52$. 
Notwithstanding this language indicating that an actual first amendment violation occurred, Professor Strauss insists that the "most natural interpretation of the first amendment is that all it requires is that persons not be prohibited from distributing leaflets for improper reasons." ${ }^{84}$ With this premise, Strauss argues that Lovell's requirement of standards to guide discretion functioned prophylactically by conclusively presuming bad motives. Such rewriting of cases, of course, can make prophylactic rules appear to be everywhere.

Professor Strauss also overlooks the possibility that the Constitution itself may act instrumentally. That is, the first amendment may prohibit standardless licensing discretion not as an evil in itself but because of a concern that such discretion too easily will permit license denials for the "wrong" reasons. Under such a reading, standardless discretion nevertheless violates not a Court imposed prophylactic rule but the Constitution itself..$^{85}$ If this is how Lovell read the first amendment-and this reading, unlike Professor Strauss's, comports with the Court's language-its holding cannot be analogized to what the Court said it did in Miranda.

Although space does not permit refutation of Professor Strauss's description of other constitutional doctrines as prophylactic, the argument would proceed along the same lines. Nevertheless, Professor Strauss has suggested an appropriate subject of inquiry, for one requisite of a constructive debate is that we know the scope of the issue.

84 Strauss, 55 U.Chi.L.Rev. at 196 (cited in note 71).

ss See Grano, 80 Nw.U.L.Rev. at 118 \& n.101 (cited in note 9). See also id. at 155-56 (discussing the first amendment overbreadth doctrine). 